\title{
THE FISHERTON MONSTER: SCIENCE, PROVIDENCE, AND POLITICS IN EARLY RESTORATION ENGLAND*
}

\author{
HARRIET LYON
}

Christ's College, Cambridge

\begin{abstract}
This article reconsiders the significance of an episode of monstrous birth in Fisherton Anger, Wiltshire, in 1664. Tracing the influence of natural philosophical, spiritual, and providential impulses in extant accounts of the Fisherton birth, it suggests that in order wholly to comprehend this material it is necessary to move beyond debates about the 'rise of science'. It therefore explores the contemporary claims made about the Fisherton monster against the backdrop of the aftermath of the Civil Wars and Interregnum, suggesting that the rampant politicization of monstrosity after the outbreak of war in 1642 provides the key to understanding the emphasis on different kinds of natural, spiritual, and moral truth in accounts of physiological abnormality after 1660. A case study of early Restoration efforts to negotiate the instability of past events, this essay further argues that the impulse to forget which underpinned the Indemnity and Oblivion Act (1660) found different expression elsewhere in the form of censorship and beyond the political sphere in the field of natural philosophy. Considered in light of this early Restoration culture of amnesia, the Fisherton monster embodies a series of attempts to forget the passions of a turbulent political past.
\end{abstract}


Between one and two o'clock in the morning on 26 October 1664, Mary Waterman, the wife of John Waterman, an ostler from the parish of Fisherton Anger near Salisbury, came to the end of a difficult first pregnancy. She had given birth to female triplets, an exhausting delivery under normal circumstances but made all the more arduous by the fact that her second and third daughters shared the single pair of legs from which protruded two complete torsos, pairs of arms, and heads. Born alive and seeming at first to thrive, the conjoined twins were baptized Mary and Martha, but they lived only two days, dying within fifteen minutes of each other on the morning of 28 October. The next day at four o'clock in the afternoon, local physicians performed a dissection of the twins, detailing every aspect of their unusual physiology. Reports of the procedure suggest that they had already come to think of their subject as the Fisherton 'monster'. After the dissectors had finished their work, the body was sewn up and embalmed, before being displayed to the paying public in Winchester, Oxford, and London. It was some months before interest in the monster died down. Not until 20 February 1665 were Mary and Martha returned to their family in Fisherton and finally buried in the parish cemetery.

Though the twins had lived barely forty-eight hours, in their afterlife as the Fisherton monster they were to enjoy several months of seemingly widespread fame. Word of the case soon reached the community of natural philosophers at the Royal Society of London, who began a lengthy correspondence with witnesses to the dissection. News of the monster also filtered through into cheaper and more widely disseminated forms of print, some of which adapted the conventions of the natural philosophical genre to reshape the Society's account of the Waterman twins in ways more consistent with a preoccupation with human morality and divine providence than with 'scientific' empiricism. The considerable degree of slippage between these 
genres has provided the focus for Stephen Pender's account of the episode, which he uses to question the idea that the late seventeenth century witnessed the 'disenchantment of the world' and a 'rise of science' that eclipsed discourses of providence and the supernatural and widened the chasm between elite and popular cultures. ${ }^{\mathrm{i}}$ Instead, Pender suggests, the Fisherton monster provides a case study of the tendency for teratological writing more generally to exhibit 'a more fluid interchange between the portentous and the merely anomalous' than permitted by narratives of scientific progress. ${ }^{\text {ii }}$ Whilst Pender has used the Waterman twins to illuminate providentialism, this article considers the case from a different perspective, exploring the extant accounts of the Fisherton monster as a series of responses to the memory of a period of profound political instability.

What follows traces the influence of natural philosophical, spiritual, and providential impulses in contemporary approaches to the Waterman twins, arguing that only by setting this episode in the context of the immediate aftermath of the Civil Wars and Interregnum does it become possible wholly to comprehend attitudes towards the Fisherton birth. This article explores firstly the Royal Society's response to the Fisherton monster as the product of a deliberate rejection of partisan politics before moving to consider how cheap printed accounts also owed something to the experience of civil war. It uses the politics of monstrosity to offer fresh insight into the ways in which the political culture of the early 1660s was shaped by processes of remembering and forgetting the 1640s and 1650s. David Cressy, Matthew Neufeld, Mark Stoyle, and Blair Worden have all explored the significance of the politics of memory to early Restoration society and culture, demonstrating the strength of contemporary engagement with the recent past through a variety of means, including state policy, commemorative practices, written histories, and the evolving public 
image and folk memory of the conflict and its key protagonists. ${ }^{\text {iii }}$ This literature has focused overwhelmingly on how the 1640s and 1650s were remembered in the later Stuart period, as contemporaries, both consciously and unconsciously, found various ways to defy the Act of Indemnity and Oblivion (1660) imposed by the state to pardon and forget past crimes. ${ }^{\text {iv }}$

This article reverses the emphasis on remembrance to probe other aspects of the process of forgetting the past through natural philosophical and providential responses to a particular episode of monstrous birth. In doing so, it explores the redefinition in the 1660s of what was politically permissible in accounts of unusual phenomena but also looks beyond the 'political nation' that provides the focus for Neufeld's recent study of the 'public remembering' of the Civil Wars. "Focusing on the natural philosophers and moral commentators who located natural, spiritual, and moral forms of truth within physical deformity, it argues that these alternatives to politicized accounts of monstrosity have the capacity to illuminate the politics of amnesia engendered by the conflict of the 1640s in the early Restoration era. A case study of the ways in which contemporaries sought to negotiate the experience and memory of civil war and interregnum, the Fisherton monster embodies a series of attempts to forget the turbulent political past.

I.

But for the notoriety they enjoyed as the 'Fisherton monster', Mary and Martha Waterman might have been consigned to oblivion. The daughters of an ostler and his wife, they were born into a social group identified by Paul Slack as the 'honest' sort 
of labouring poor. ${ }^{\mathrm{vi}}$ The extent of the family's hardship was revealed by one witness to the birth, a physician named William Hann, who described the Waterman home as a poorly appointed dwelling, 'full of holes, to let in the air, which at that season was pretty cold and sharp', and the monster as having 'only a linen cloth for its covering, which was taken off at the desire of every new spectator'. vii Samuel Pepys's account of the twins, gleaned through conversation with an acquaintance at Whitehall, echoes this description and implies that financial considerations were key to the Waterman family's decision to display their daughters to the public, suggesting that the sisters died after 'being showed too much to people'. viii By virtue of their poverty and relative obscurity, few traces of their short lives survive in the historical record. The Fisherton parish register confirms that the twins were baptized on 26 October 1664 and buried some four months later on 20 February $1665 .{ }^{\text {ix }}$ But the form of the register prevented any reference to Mary and Martha's unusual physiology or to the fact that they had died long before the date of their burial. Rather, to find traces of the Waterman twins' life we must turn to those sources that helped to create an afterlife for the Fisherton monster.

As a monstrous birth, the Waterman sisters fit well-established tropes of teratological literature. Conjoined twins were perhaps the most commonly reported type of monstrous birth in the early modern period, accounting for a little over a third of the 249 printed and publicized accounts of human deformed births identified by A.W. Bates for the period 1500-1700, and Mary and Martha's birth in October 1664 was the second such occurrence that year, after another pair of similarly short-lived 'double' twins was born in Vienna in March. ${ }^{\mathrm{x}}$ In respect of the overall population such cases remained a rarity, but, partly by reason of their infrequency, they fuelled a significant market for printed reports of deformed births sustained by a voracious and 
widespread interest in monsters and other unusual phenomena. ${ }^{\mathrm{xi}}$ In this context, it is little surprise that the Fisherton monster was to attract attention far beyond the boundaries of the parish in which the Waterman twins had lived and died.

The first that Robert Boyle, noted natural philosopher and founding member of the Royal Society, heard of the Fisherton monster came in the form of two letters written at a time when the twins were still living and delivered to him in Oxford on or before 30 October. ${ }^{\text {xii }}$ The first of Boyle's correspondents, the Salisbury oculist Daubeney Turberville, offered a description of the 'monstrous issue': two children who 'hath but one Body' with 'foure Armes completely made, two Necks \& heads very well featur'd, with all the parts, but they are contrary posited' and only 'two compleat Leggs'. For Boyle's reference, he presented a comparison with the conjoined twins depicted in Jacob Rueff's De conceptu et generatione hominis (1554) and enclosed his own sketch - completed 'as well as my fancy enabled me' - roughly delineating the basic outline of the sisters (Figure 1). The spectacle, he wrote, had already brought 'a thousand' people to the Watermans' door. Amongst this stream of visitors was William Hann, with whom the second of Boyle's reports is presumed to have originated. ${ }^{\text {xii }}$ Confirming Turberville's description of the 'strange misshapen birth', Hann too found similarities between the case and Rueff's 'partus Monstrosus', the short lifespan of which encouraged him to think that it would not be long before a dissection could take place. 'If any more Discoveryes be made of it by a Dissection after Death,' he wrote to Boyle, 'you shall not faile to have Notice of it'. Reflecting the popularity of monsters as a topic of discussion at the Society, Boyle echoed this hope that further information might be made available 'if this Monster proves not longer liv'd then Creatures of that sort are wont to bee' in his letter to Oldenburg. ${ }^{\text {xiv }}$ 
Of course, though he could not have known it at the moment of writing, Mary and Martha had already died.

Hann and Turberville were amongst the first witnesses to the Fisherton monster; their reports are the earliest extant accounts of its birth and precipitated a flurry of correspondence that advanced a very particular empirical, natural philosophical account of the twins' monstrosity. Both physicians constructed their reports around what they had witnessed of the Fisherton monster, communicating as best they could its physiology and employing a descriptive and emotionally detached approach to their subject. In other words, they were concerned with what could be observed of the Fisherton monster and not what it might mean or signify. But when Oldenburg presented their findings to the Society on 2 November, it quickly became clear that both physicians had fallen short of the fellows' expectations. Their accounts lacked the detail that could only be achieved by dissection. Particularly problematic was Hann's sketch, which was a poor approximation of the twins, having been drawn in such a way as to make the body of the twin pictured at the top of the paper seem much larger than that of the second twin, the rendering of which was generally less well executed. Boyle himself made no great claims for the authority of the image, which he called only a 'kind of delineation'. ${ }^{\mathrm{xv}}$ Intrigued but not yet convinced of the authority of the reports, the Society demanded that Oldenburg procure the 'best attestation' of the case 'before it should be registered'. ${ }^{\text {xi }}$

The Society's attempts to solicit the 'best attestation' of the Fisherton monster reflect its pursuit of a certain kind of truth about the natural world. Though it was at the heart of what has been called the 'new experimental science' of the 1660s, the Society took direction in this endeavour from the past in the form of the writings of Francis Bacon, late-Tudor politician turned early-Stuart natural philosopher. ${ }^{\text {xii }}$ 
Bacon was deeply committed to the technological, observational, and experimental aspects of the experience of nature. His first aphorism in the New organon (1620) declared that 'Man is Nature's agent and interpreter; he does and understands only as much as he has observed of the order of nature in fact or by inference; he does not know and cannot do more'. ${ }^{\text {xiii }}$ Bacon went on to address the issue of monsters, urging his reader to 'bid farewell to all superstitious stories' ${ }^{\mathrm{xix}}$ and replace these fallacies with a 'collection or particular natural history' of monsters, under a broader category not of the supernatural, but of 'abnormality in nature'. ${ }^{x x}$ What Bacon offered the Society virtuosi was a new kind of fact detached from theory and derived only from observation and experiment. ${ }^{\mathrm{xxi}}$ This was, therefore, a new kind of natural truth, which, as we shall see, was part of the Society's undertaking explicitly to position itself against the passions of the civil war past.

It was to the exploration and communication of natural truth that the Society directed its energies. In 1665, less than a year after the monstrous birth at Fisherton, Oldenburg wrote a preface for the first edition of the Philosophical Transactions, in which he justified the Society's endeavours to the end that the virtuosi 'may be... encouraged to search, try, and find out new things, import their knowledge to one another, and contribute what they can to the Grand design of improving Natural knowledge' ${ }^{x i i}$ Though what Michael Hunter has termed the 'corporate identity' of the Society should not be confused with the activities of its individual members - early members were known, for example, to profess magical beliefs - the writings of the fellows demonstrate an obvious preoccupation with the merits of rational observation and experiment. ${ }^{\text {xxii }}$ These combined to form an account of experience, which had emerged as a form of authority on the continent in the early seventeenth century and was now the pillar of credibility for the Society. ${ }^{\text {xxiv }}$ 
The Society's desire for detail in the case of the Fisherton monster was satisfied when Hann, fulfilling his earlier promise to Boyle, wrote again of the Waterman twins, informing him of their death and supplying a full report of the subsequent dissection. Hann's letter arrived in London on 9 November, together with another account written by a Salisbury gentleman named Roger Baskett, who summarized the basic findings of 'Heartes 2 Lungs 2 Midriffs 2 Stomacks 2 Livers 3 Galls 2 Spleenes 2 Kidneys 3... \& Bladder and Womb'. But Hann's account, written in Latin, was the more detailed report, exhaustively recording his observations of the brain, heart, lungs, trachea, mediastinum, thymus, diaphragm, arteries, veins, pylorus, stomach, intestines, liver, bladder, spleen, pancreas, kidneys, womb, pelvis, spinal vertebrae, sacrum, and genitalia. ${ }^{\mathrm{xxv}}$ It was also accompanied by a new set of images. ${ }^{\text {xxvi }}$ Like Turberville's effort, these images were hand drawn, but with a great deal more care and accuracy. The positioning of the torsos more exactly reflects the physiological details provided in the written accounts and each of the images shows the body from a different angle: from the front, from the back, and laid open for dissection (Figures 2, 3, and 4). There is no great detail of the internal anatomy, but the shape of the bodies is well captured and the use of a naturalistic style effectively conveys the youth of the twins.

Hann's attempt to capture a realistic image of the newborn sisters corresponds with recent scholarship highlighting how images were a key component in the making of early modern natural philosophy, in which the depiction of an object or experiment delineated truth. ${ }^{\text {xxvii }}$ Peter Parshall has suggested that images were more than artistic creations, they were devices that could display and convey the knowledge of the artist. ${ }^{\text {xxviii }}$ Thus images functioned not only to reinforce the natural or moral truth conveyed in the text, but also to make their own truth claims about what it was 
to see a monster - and at the Society this meant seeing the Fisherton monster as a physiological anomaly. Because of the emphasis placed on observation, sight in early modern scientific culture functioned to facilitate the pursuit of credibility. Images therefore gave the viewer the vicarious experience of seeing the object itself, giving a cross-section of a particular time and place. In the case of the Society, Sachiko Kusukawa has argued that this function of images in the dissemination of knowledge meant that they also expressed something of its 'institutional ideals' ${ }^{x x i x}$ The rhetoric of the Society emphasized the importance of conveying the particulars of an experience, with veracity dependent on the time and place of that experience - 'the procedure could always be repeated; the event could never be'. ${ }^{\mathrm{xxx}}$ The representation of experience was also a function of images and, because of this, images 'had a substantial role in the regular meetings of the Royal Society' ${ }^{x x i}$ Thus it is unsurprising that some of Boyle's correspondents on the matter of the Fisherton monster also included images as part of their claim to advance a truthful account of Mary and Martha Waterman.

But still the fellows were not satisfied and pressed Hann for an even greater level of detail, complaining that 'the Company wished that the Dissector of the Double-Child had more distinctly and particularly expressed what vessels were common'. ${ }^{\text {xxii }}$ There was also a more serious problem. When Boyle sent Turberville and Hann's first accounts to Oldenburg he had cautioned that 'not having been an eye witnesse [to the Fisherton monster] my selfe, all that I can doe is faithfully to transcribe the Relation sent me from the place where the Monster was borne in the very words of the Relators' xxxiii It was critical that the 'Relators' be proven reliable witnesses. But despite Boyle's knowledge that the letter originated with Hann, the physician had failed to sign his name to the document. 'I am sorry,' Oldenburg wrote 
to Boyle on 17 November, 'the Dissector of the Double-child did not put his name to the account... and we must contrive some way or other to have it yet done, for the more authentickness of the relation'. xxxiv

The authority of a witness was especially important where the Society had not seen an experiment firsthand. Moreover, as Palmira Fontes da Costa has suggested, the inherent implausibility of extraordinary phenomena such as monsters, which by definition do not conform to general experience, placed particular significance upon the value of testimony. ${ }^{\mathrm{xxv}}$ This connects with Steven Shapin's emphasis on the role of trust in forming truth. He argues that there was then, as now, a connection between what was known of monsters and what was known of the people who claimed to know about monsters. ${ }^{\text {xxvi }}$ It is clear that the Society received information on the Fisherton monster from sources trusted by its members. Boyle wrote of Turberville, for example, that he was 'deservedly famous' in Wiltshire for being an 'Excellent Oculist'. ${ }^{\text {xxvii }}$ But pieces of paper could not be trusted if they did not contain the autograph of their author, however eminent or trustworthy. This was expressed clearly by Oldenburg when he wrote to Boyle concerning Hann's missing signature, commenting that it was the 'registering of the person' communicating new information, in combination with the time and place of the event, that constituted an account that could be 'inviolably preserved to all posterity' ${ }^{\text {xxxiii }}$

The Society's demands were met when, on 29 November, Hann wrote again to Boyle, apologizing for his imperfect second account and submitting a third, which included additional details such as the composition of the embalming lye and, crucially, bore his signature. ${ }^{\text {xxix }}$ The Society had finally obtained an account of the Fisherton monster that was both the record of detailed observation and an example of authoritative testimony, the twin hallmarks of credibility and the means by which the 
Society pursued its particular brand of natural truth. The Society's process of review and endorsement is suggestive of how it was in some sense the arbiter of natural truth and could, as da Costa has suggested, facilitate a kind of 'collective witnessing' at its meetings. ${ }^{\mathrm{xl}}$ In his first report, Hann had explicitly invoked the language of truthfulness, claiming that 'I have here enclosed... the description and delineation of [the Fisherton monster], and can assure you (if I may believe my own eyes) I have written the truth'. ${ }^{\text {xli }}$ But this account was rejected by the Society, which both required evidence of truth and also conferred truthfulness upon those accounts which it endorsed. Its response to events in Fisherton was both to seek and to confirm natural truths about the monstrosity of the Waterman twins.

II.

In adopting this stance, the Society consciously rejected the alternative conception of monstrosity as an emblem of political truth that had flourished during the 1640s. Derived from monstrare ('to show') and monere ('to warn'), the very name of 'monster' made implicit claims to truth and revelation. ${ }^{\text {xlii }}$ For centuries this had created monsters fraught with providential implication but, as Kathryn Brammall has argued, it also inspired the development of a politicized 'rhetoric of monstrosity' from the mid-sixteenth century, which functioned both as an interpretive framework with which to explore genuine physical deformity and as pure allegory. ${ }^{\text {xliii }}$ Over the course of the early modern period, monstrosity became a 'highly exploitable instrument of propaganda' used to malign supposedly monstrous beliefs and behaviours. ${ }^{\text {xliv }}$ The full 
potential of this rhetoric was to become plainly apparent during the conflicts of the mid-seventeenth century.

Fought on paper and in printer's ink as well as on the battlefield, the Civil Wars pitted elements of the national body against its sovereign head, Charles I. This instilled considerable creative potential in the monstrous body and, facilitated by the lapse of licensing laws with the abolition of Star Chamber in 1641, monsters came to occupy a particularly prominent position in satire and polemic. In some instances deformity was deployed metaphorically to transform religious belief and political conviction into visible bodily aberration. One such broadsheet, written by an anonymous Parliamentarian in 1643, implored its reader to 'looke upon this monstrous Thing', in the form of a double-bodied, many-headed papist-Royalist, 'that would our Kingdome unto ruine bring' xlv But instances of apparently genuine physical deformity were no less powerful for their corporeality. Monstrous births functioned as portents of political triumph or defeat and reflections of the political deviancy of their begetters. Thus in A declaration of a strange and wonderfull monster (1646), a child with a deformed head born to a 'popish gentlewoman' in the parish of Kirkham in Lancashire was interpreted as the tangible consequence of his mother's monstrosity of conviction, of her wish 'rather to bear a Childe without a head than a Roundhead' ${ }^{\text {xlvi }}$ The narrative was embellished by a woodcut depicting the child adopting an unnaturally upright and aggressive stance, surrounded by images of his mother clutching a rosary and cruelly docking the ears of cats in a mockery of the punishment of the puritan polemicist William Prynne (Figure 5). To the anonymous Parliamentarian interpreter, the message communicated in the body of the Kirkham monster was clear: Royalism was a monstrous condition and deserved to be punished in kind. Yet elsewhere, supporters of Charles I claimed that it was the Parliamentarian 
- the 'Roundhead' - who inhabited the truly monstrous body. ${ }^{\text {xlvii }}$ The monster had become emblematic of a society divided.

The Royal Society's account of the Fisherton monster owed a great deal to the desire to move beyond this partisan conception of monstrosity. Michael Hunter has argued that Restoration natural philosophy was profoundly shaped by a 'widespread revulsion' amongst the intellectual elite of the radicalism that had been a defining feature of the Civil Wars and their aftermath. ${ }^{\text {xlviii }}$ The embryonic Society had met in Oxford clubs during the 1650s, during which time its very operation had relied on its members, who included both committed Royalists and ardent Parliamentarians leaving their political convictions at the door. ${ }^{\text {xlix }}$ Formally founded in November 1660 and granted a royal charter in July 1662, the Society continued in its aim to transcend partisan politics in the Restoration period. The key figures in the Fisherton case exhibited a variety of political views. Oldenburg's instincts were Parliamentarian, though he endorsed the Restoration settlement, as did many of his contemporaries. ${ }^{1}$ Boyle meanwhile was concerned only with effective government and 'displayed a wish... to transcend sectarianism' ${ }^{\text {li }}$ The political opinions of most of the Wiltshire correspondents are obscure, but it is clear that Daubeney Turberville had been a committed Royalist and participated in the defence of Exeter in 1645, before settling in Salisbury as a physician. ${ }^{\text {lii }}$ The rejection of political agendas was also enshrined in Thomas Sprat's early manifesto for the Society, The History of the Royal Society of London (1667). ${ }^{\text {liii }}$ He wrote that its 'first purpose was no more, then onely the satisfaction of breathing a freer air... without being ingag'd in the passions, and madness of that dismal Age' liv This impulse was reflected in the detached, detailed, and observational style adopted by the Society in its correspondence and publications. During the 1640s, Sprat claimed, language itself had become effectively monstrous - 
'the Ornaments of speaking' had become 'so much degenerated', the cause of 'so great a noise in the world' - and this could only be remedied by a new genre of natural philosophy marked by 'a constant Resolution, to reject all the amplifications, digressions, and swellings of style'. ${ }^{\text {lv }}$

Certainly the account of the Fisherton monster endorsed by the Society bore none of the hallmarks of the political monsters of the 1640s. Rather Hann's report exemplifies an empirical methodology which sought to undermine the credibility of politicized monsters by developing new standards for the interpretation of physical deformity. So critical were these methods to natural philosophical endeavours that Peter Dear has suggested that 'the style of science espoused by the Fellows of the Royal Society was more important than the substance of that science'. lvi The Society had developed a genre of explanation and communication which self-consciously rejected the partisan politics of the 'dismal Age' of civil war. When Hann claimed to have 'written the truth' after observing the dissection of the Waterman twins, he - like his colleagues Turberville and Baskett, Boyle and Oldenburg - located that truth in what could be observed of the monster, rejecting the sense in which polemicists located political meaning in prodigies like the Kirkham monster in favour of the firsthand experience of natural truth.

But though the Society rejected the passions of partisan politics, it would be wrong to assume that the endeavours of its members were irreligious or that its account of the Fisherton monster was devoid of spiritual meaning. The Society's selfconsciously Baconian mission statement has lent credence to the idea that the early modern period witnessed a 'rise of science'. Following the Weberian thesis of the 'disenchantment of the world', it has been suggested that one effect of the Protestant Reformation was to eliminate magic from religion through the rejection of all 
superstition, thereby fostering a culture in which the supernatural - including monsters - became outmoded in everyday religious life. ${ }^{\text {lvii }}$ Thus Lorraine Daston and Katherine Park's seminal article on 'unnatural conceptions' argued that 'for the educated layman... and even more for the professional scientist... the religious associations of monsters were merely another manifestation of popular ignorance and superstition, fostering uncritical wonder rather than the sober investigation of natural causes' lviii

However, more recently it has been suggested that Restoration natural philosophers, far from being the harbingers of secularization, were actually engaged in the pursuit of Christian 'wonder'. The prevailing early modern worldview affirmed that nature reflected a divine order. ${ }^{\text {lix }}$ Monsters had long been considered part of an orderly creation and were not only evidence of singularity in nature but also revealed something about the right, true order of the world. ${ }^{\mathrm{x}}$ Though this idea was rarely articulated in the correspondence or publications of the Society, it was embedded in the wider outlook of the virtuosi. The naturalists and collectors of the sixteenth and seventeenth centuries, as Paula Findlen has argued, 'subsumed their philosophical speculations within a highly Christianized framework' in which nature was a book of God's works, which could be read in the same way as any physical text. ${ }^{\text {lxi }}$ Katie Whitaker has suggested that the principles of the reasoned and articulate culture developed in institutions like the Royal Society meant that 'true wonder' was the preserve of the 'Christian curioso' observing 'the true Works and wonderful Contrivances of the Supreme Author'. ${ }^{\text {xii }}$ She suggests that observation and experiment therefore constituted an attempt to experience nature as Christian wonder. For this reason, reports of the Fisherton monster had to be both accurate and true in order to produce genuine wonder: 'they had to be "particular", describing all the 
details of the phenomenon minutely and circumstantially' and 'show care and diligence which ensured their reliability'. ${ }^{\text {xiii }}$ Religious language may have been largely absent from their writings, but Restoration natural philosophers were far from impious.

Sometimes this worldview came into conflict with other patterns of interpreting monstrosity. In the covering letter to his final report, Hann relates how he first heard about the birth at Fisherton whilst taking refreshment at a local coffeehouse. According to Hann, 'the company seemed somewhat to wonder, how $\mathrm{Mr}$ Kent, minister of Fisherton, could justify the baptizing it with two names, adding, that it was a question to be debated by divines, whether it were to be reckoned as two persons, and whether it had two souls'. ${ }^{\text {xiv }}$ Evidently Hann did not share this view because he replied 'that the divines must be beholden to the physicians for the determination of [this question]', though the Fisherton parish register confirms that the twins were baptized individually. He went on to deploy his arguments for the merits of empirical method in debate with John Waterman, an outsider to the gentlemanly culture of natural philosophy, who initially refused to allow the dissection of his daughters, saying that 'if he should suffer it, he should offend God'. ${ }^{x v}$ It took the continued efforts of Hann and several others of his colleagues to ensure that the dissection took place. But though his responses to Kent and Waterman undoubtedly privileged natural philosophical experiment over religious claims to the interpretation of the Fisherton monster, Hann's was no less a spiritual position than those of his interlocutors. Rather he epitomizes the view that investigation into the order of the natural world was work for the virtuosi rather than the church.

Thus the natural truths conveyed in the writings of the Society were not incompatible with a sense of spiritual truth about the right order of nature and 
operated alongside the rejection of partisan politics as a key facet of the gentlemanly culture promoted by the Society. ${ }^{\text {lxvi }}$ As we have seen, for an account to be credible the correspondents themselves had to be trustworthy and this was often assessed in terms of social status. In the case of the Fisherton monster, two of Boyle's correspondents, Turberville and Hann, were physicians, and Baskett had gentle status. ${ }^{\text {lxvii }}$ Hann also relates the name of the principal dissector, a surgeon named Mr Down, and those of other credible witnesses, including Dr Haughton, an occasional correspondent of Boyle's. ${ }^{\text {lxviii }}$ The case also appeared in the notes of John Aubrey, who cited as his source the young Oxford-educated physician Thomas Guidott. ${ }^{\text {lxix }}$ These men all contributed to the civil, reasoned, and gentlemanly culture of natural philosophy that had grown up in response to the struggles of the 1640s and restricted discussion to observed phenomena. Hann's 'best attestation' of the Fisherton monster was therefore totally devoid of what Sprat had called 'passions', both partisan political and sentimental, and lacked the more emotive passages describing the dire conditions in which the twins had lived and died that appear in his informal correspondence with Boyle.

Likewise, J. R. Jacob has argued that in Boyle's case, spiritual purpose combined with his experience of the 1640 s to inspire in him a sociable approach to natural philosophy that was pious but not political: 'his involvement in the larger world produced in him a new kind of piety defined largely by the necessities, real and supposed, of revolution, and his natural philosophy grew partly out of and conformed altogether to this piety' ${ }^{\mathrm{xx}}$ The spiritual element of this worldview therefore served further to distance the Society's brand of natural philosophy from the unruly and problematic sphere of political debate and the instability created by civil war. This desire to dissociate itself from the partisan meaning of monsters resulted in the 
development of a genre of natural philosophical communication that magnified the natural truth of the Fisherton monster at the expense of spiritual response. The more informal communications received by Boyle, however, confirm that the Society's account of natural truth was also a form of spiritual truth. The Society's report of the Fisherton monster was in its own way a religious approach to monstrosity and, moreover, one that further distanced their endeavours from the vitriolic and divisive anti-Catholic, anti-Royalist polemic of the Kirkham monster - from the 'passions' and partisan politics of civil war.

III.

The Society's approach to the Waterman sisters' monstrosity also had purchase outside the walls of Gresham College and cheap printed accounts of the Fisherton monster too owed something to the memory of past politics, albeit in a different sense to the natural philosophical genre from which they sometimes borrowed. At the same time that Hann was writing up his observations in Salisbury, ninety miles away in London, Roger L'Estrange, Charles II's surveyor of the press, was authorizing the publication of the first account of the twins to appear in print. By the time the Society met on 9 November, The true picture of a female monster born near Salisbury (1664) was already in public circulation in the capital informing its readership that Fisherton had witnessed the birth of a 'wonderful Creature, which cannot be otherwise accounted [than] a Monster'. The first of two cheap prints of the Fisherton monster, The true picture bears testament to the influence of natural philosophical ideas beyond the Society. Like Hann's account, The true picture also favours a descriptive 
style, with evidence apparently drawn from firsthand observation, though clearly the anonymous author was not bound to the same standards of evidence as the virtuosi since he did not seek to claim veracity either by giving his own name or that of his witness. The basic detail corroborates what was discussed at the Society, though this account is much shorter, describing only a monstrous birth with 'two Heads, four Arms, and two Legs' joined together 'just in the middle' by the navel, with 'all the inward parts complete... except only that it had but two kidneys'. The apparent error in this observation - the reports received by Boyle agreed that there were three kidneys found in the body - is one indication that some or all of the information given in The true picture might be second hand. Linguistically, the account is also reminiscent of the highly descriptive and emotionally detached reports received by the Society. It is entirely possible that both of these factors can be explained as the result of the conventions imposed on the print by its intended purpose, as it may have been an advertisement for the display of the monster. The final line informs the reader that the embalmed body of the twins was 'intended speedily to be brought to London' and, as Boyle's correspondence suggests, it was indeed exhibited in the city. ${ }^{1 x x i}$

The true picture also features a highly detailed woodcut (Figure 6) very similar in content and style to that drawn by Hann. Centrally positioned and taking up a little less than a third of the page, the image depicts the twins standing on a sack, the legs at a perpendicular angle to the torsos. Though they have been made to appear to stand as upright as the Kirkham monster, this image, like those presented to the Society, exhibits none of the narrative embellishment of the headless aggressor. Indeed it seems that the twins are shown in exactly the same position as in Hann's sketches. The engraving has also been rendered with considerable realism - the physiques are reasonably child-like, the features detailed and accurately placed. This 
style may have been employed to enhance the function of the broadsheet as an advertisement for the monster's exhibition, if indeed that was the purpose of the print. But regardless of the objective of the text, the image is itself clearly on display, communicating the truth of the monster's physiology to its audience. The very title of the print reinforces this claim to display the 'true picture' of the Fisherton monster and it was a 'truth' that borrowed not from the divisive and politicized images of monsters from the previous decades but from the contemporary genre of observational natural philosophy.

More complex was the claim to truth advanced in the second of the printed accounts of the Waterman twins. On 12 November, a week after the appearance of The true picture and at the same time as the Society was embroiled in the difficulties surrounding the validation of Hann's reports, L'Estrange licensed Natures wonder? (1664). Like The true picture, the broadsheet relates the basics of the case following the model of emotional detachment favoured by the Society: we learn the date and time of delivery, the physical attributes of the 'strange Monster', and that the body was 'imbalmed' after dissection and brought to London 'to be seen' by 'persons of quality'. lxxii The closing paragraph is, moreover, endorsed with the name of a witness, Josiah Smith, apparently a 'Practitioner of Physick', though there is no record of him as a member of either the Society or the Royal College of Physicians, nor as a correspondent of the Society's on the matter of the Fisherton monster. Nevertheless the name and rank of this supposed witness fulfill something of the same function as Hann's signature on the dissection report, enhancing the authority and credibility of the account.

The language of Natures wonder? also indicates that information was being relayed from sources within the natural philosophical community to authors 
outside it, either through correspondence or in conversations like the one reported by Samuel Pepys. For example, Smith relates some detail missing from The true picture but apparent from the Society's communications, including the names of the twins and the fact that they were baptized. He also employs similar terms to the Society's correspondents when recounting the anatomical features of the twins, including the term 'fundament' to mean the lower part of the body. There is also evidence of crossover between Smith's account in Nature's wonder? and that of The true picture. The full title of Natures wonder? describes a monster with 'the Heads standing contrary each to the other; and the Loines, Hipps and Leggs Issueing out of the middle', using markedly similar language to The true picture, which depicts 'the Heads standing contrary each to other... The Loyns, Hips and Legs issued out of the sides of the Bodies, just in the middle'. Both describe the surviving Waterman daughter as 'a very comely Child in all proportions'. But there are also inconsistencies. For instance, Natures wonder? gives John Waterman's occupation as 'ostler', as stated in Baskett and Hann's accounts, and not 'husbandman' as given in The true picture. In all likelihood, then, the prefatory and concluding material in Natures wonder? was drawn from two or more other accounts of the Fisherton monster, which probably included The true picture and may have included information from Boyle's correspondents, perhaps Hann's account, which had by his own admission 'travelled east and west'. lxxiii

The title 'Natures wonder?' recalls the form of natural-spiritual truth developed by the Society and its correspondents, though the question mark raises a hint of doubt, itself acknowledging the ambiguity in the status of the Waterman twins - physical aberration or divine wonder? This is also achieved in the text by the juxtaposition of Smith's narrative with a blackletter providential ballad, which 
explicitly interprets the Fisherton monster according to the tradition that conceptualized monsters as signs of divine intervention in the world. Whilst the conventions of the natural philosophical genre prevented the Society virtuosi from deploying moralizing or overtly spiritual language, the author of the ballad in Natures wonder? was bound by no such constraints. The ballad highlights the 'grievous Paines' of the mother, the 'woefull misery' of the twins, and the deep grief of both parents. Roger Baskett, for instance, had said only that Mrs Waterman had been 'in as Good a State of Health as can be expected from A Woeman in Child Bed', showing a disregard for the human tragedy of the case. ${ }^{\text {lxxiv }}$ Most of Baskett's fellow correspondents ignored the Watermans' suffering entirely. But Natures wonder? draws on the emotional power of the Fisherton monster to advance its own claims about the truth of monstrous birth:

Afflictions God doth sometimes send to Parents for their sin, When they will not their lives amend, then doth the Lord begin With Judgments for to humble them, and make them feel his hand; O turn unto the Lord in time, for none can Him withstand... Then Parents all Example take, at all times seek the Lord; Fruit of your bodies he can make by your own selves abhorr'd: 
Your Children which should be a joy

and comfort in the end,

The Lord in fury will destroy.

if you do him Offend. ${ }^{\text {lxxv }}$

An opening appeal to 'observe it [the monster] well with heed' refers not to the empirical observation preferred by the virtuosi, but rather to a different type of display, in real life and in print, which explicitly evoked fear of the monstrous: 'By this Example you may learn / to feare Gods Punishment'. But, in a further indication that they belonged to the ranks of the 'honest' poor, the ballad struggles to portray the Watermans themselves as sinful, largely disregarding a specific attack in favour of a more general moralizing tone. The format of emotionally detached testimony combined with providential reading had long been a common tactic in print of this type, especially where there was no evidence of promiscuity or extra-marital sex on the part of the parents. ${ }^{\text {lxxvi }}$ Indeed far from scorning the Watermans as unrepentant sinners, the ballad emphasizes how the living daughter was a source of 'joy' who 'cheer[ed] her Mothers heart'. But on the phenomenon of monstrous births more generally, Natures wonder? draws a clear line of causation between deformity and divine punishment.

This is also apparent from the ballad's two woodcut images (Figure 7), both small and crude compared to that of The true picture. The first depicts the twins and bears striking similarities to Hann's sketches and especially to The true picture. It would appear, in fact, that it is a poor but direct reproduction of the image in the latter: the limb placement is almost identical except that it has been reversed, a result of the copying process. ${ }^{\text {lxxvii }}$ Thus it seems likely that the artist of The true picture had 
access either to Hann's sketches or to similar images being produced in intellectual circles, such as the copy of The true picture made by John Aubrey, ${ }^{1 x x v i i i}$ and that Natures wonder? then reproduced The true picture to support its own account. Importantly, this suggests that the representation of the Fisherton monster in Natures wonder? was not a generic stock image but created specifically for the ballad. Perhaps this was a mark of the twins' growing fame, or it could easily have been the result of shared or copied ideas between the White Lion and the publisher of The true picture on Chancery Lane, two shops barely half a mile apart.

But though it deploys a visual style adapted from that which advanced a form of natural truth, Natures wonder? juxtaposes the figure of the twins with a second image in order to reinforce its particular moral message. The right-hand woodcut depicts a group of three people at prayer, presumably demonstrating the means by which the audience of the ballad might avoid a similar fate befalling their own families. This representation of prayer may, unlike the image of the twins, have been a stock image and certainly it bears no relevance to the specifics of the case. But what Natures wonder? was able to do, through images as well as text, and in a way that the Society virtuosi could not do, was advance a theory of causation that had at its core a moral truth that linked parental sin to physical deformity. An image that might in one context appear to be little more than a visualization of scientific observations was given a very different meaning in this providential ballad.

Natures wonder? thus bears testament to the compatibility of the natural philosophical and moralizing responses to monstrosity, amplifying the providential quality of the Fisherton birth but placing it alongside the notion that physical deformity was an aberration of nature. But if these printed accounts offered the Fisherton monster as an emblem of natural and moral truth, it is also striking that they 
are marked by the total absence of the kinds of partisan statements about monsters that had abounded in the genre during the 1640s. In one sense, this reflects the influence of the natural philosophical approach to monstrosity. But there remains the possibility that these broadsheets were also the product of a different attempt to negotiate and forget the political monsters of the recent past.

IV.

An unusual episode in the first months of restored Stuart monarchy made it abundantly clear that the political potency of unusual phenomena had not waned with the restitution of the sovereign head to the national body. In August 1660, the town of Fairford in Gloucestershire witnessed a plague of frogs and toads 'marching in two companies, even as soldiers in a field', which was interpreted by local puritans as a providential punishment for the harassment and ill-treatment they had been suffering at the hands of the Fairford authorities. ${ }^{\text {lxxix }}$ This sparked a bitter debate over the meaning of the prodigy, drawn along the politico-religious divisions that existed in the town in the uncertain and fractious first months of the Restoration. First published by an anonymous puritan minister as Strange and true news from Gloucester (1660), the puritans' claims were subsequently rebuked by a local Anglican minister, Robert Clark, whose own pamphlet, The lying wonders (1660), prompted further rebuttal from the puritans, who pointed to the plague of flies that had followed the frogs and which, they argued, 'must surely testify to God's judgement'. ${ }^{\operatorname{xxx}}$ The debate surrounding the Fairford prodigy was couched in the language of truth - and particularly in the language of political truth, as opposed to the other variants in 
evidence in the case of the Fisherton monster. The initial report of the marching frogs purported to be 'true news', whilst the flies were interpreted by the puritan faction as certain evidence of divine displeasure. Yet Clark had dismissed these puritan pamphlets as 'groundless lies', arguing that the infestation of frogs did not constitute an amphibian army. ${ }^{1 \mathrm{xxxi}}$ The truth of the prodigious flies and frogs was thus both overtly political and hotly disputed; like the monsters of the 1640s, the Fairford episode evidences the instability of the category of the monster as a result of the rampant politicization of unusual phenomena during the previous decades of civil strife.

After 1660 the strong Anglican stance adopted by the state had the counterproductive effect of entrenching this embattled sectarian culture in Restoration society. In this context, the politicization of monstrosity was one aspect of a political culture in which truth itself had become a distinctly plural and partisan concept. ${ }^{\text {lxxii }}$ This had profound implications for the interpretation of prodigious occurrences and monstrous bodies. Jerome Friedman has argued that it was through visible and tangible 'miracles, apparitions, and monsters', as opposed to debates over ideas and institutions, that most people made sense of the 'inexplicable crisis' in politics and religion posed by the growth of pluralism in the 1640s and 1650s. ${ }^{\text {lxxxiii }}$ Indeed William E. Burns has suggested that, 'precipitated' by the entrenchment of pluralism after 1660, the Fairford frogs, alongside the thinly disguised anti-government politics of the notorious Mirabilis Annus tracts (1661-2), came to 'define the terms of the debate over prodigies for the rest of the seventeenth century'. ${ }^{\text {lxxiv }}$ Despite abstaining from overt political commentary, the Mirabilis Annus pamphlets nevertheless harnessed prodigies as signs of the sinfulness and weakness of the monarchy, adopting 'the apocalyptic tactic of delegitimizing the regime through the sheer quantity of prodigies 
alleged to have taken place in the preceding "Year of Wonders"' in the wake of the return of royal government. ${ }^{\operatorname{lxxv}}$ These tracts, like the Fairford controversy, contributed to a political culture in which partisan providential interpretations of monstrosity had come to be closely associated with hostility to Charles II and the Restoration settlement. The Fisherton monster was the product of the subsequent assault on this tendency launched by defenders of the Stuart regime.

Clearly by 1664 circumstances had conspired to discourage a political reading of the Waterman twins' monstrosity. The climate for publishing had changed dramatically since the pamphlet wars of the 1640s and the first uncertain months after the Restoration in 1660. It is particularly telling that both extant printed accounts of the Fisherton monster bear the authority of the Stuart monarchy in the mark of its licenser. Having campaigned for renewed censorship since the accession of Charles II, L'Estrange's cause had been rewarded with the Licensing of the Press Act (1662) and L'Estrange himself with the office of surveyor in August 1663, which extended his reach over genres not included in the Press Act, including medical publications, and gave him a monopoly over broadsheets and other material that used fewer than two sheets of paper. ${ }^{\text {lxxvi }}$ His remit included powers 'to seize all seditious books and libels' and L'Estrange policed texts both pre- and post-publication, attempting to ensure his presence was felt at the stages of authorship, printing, and reading. ${ }^{\text {lxxxvii }}$ Moreover, the Press Act functioned both to impede the publication of patently polemical readings of monsters and to facilitate a culture of self-censorship, in which, as Annabel Patterson has argued, the risks of writing such work outweighed the rewards and subtle allegory and allusion became a more viable form of political critique. ${ }^{\text {xxxviii }}$ Indeed subversive prodigy tracts of the ilk of the Fairford and Mirabilis 
Annus pamphlets were among the particular targets of this 'devastating attack on the underground press, ${ }^{\text {lxxxix }}$

Though it is impossible to say whether the Fisherton authors were selfcensoring their accounts, given the subversive associations of prodigies it seems no coincidence that the only accounts of the Fisherton monster to reach the presses were published under L'Estrange's imprint and entirely devoid of political references. In a different way from the Society virtuosi, L'Estrange - partly as the condition of his employment by the Crown and in the interests of the state - rejected and sought 'with inquisitional zeal' to control the partisan politics that had characterized the past. ${ }^{\mathrm{xc}}$ As a government official and ardent supporter of the regime, he could only have published Natures wonder? and The true picture if they could be guaranteed politically inoffensive. ${ }^{\mathrm{xci}}$ Clearly both the natural philosophical and providential elements of Natures wonder? were sufficiently innocuous to make it past the licensers. Censorship may have had its limits, but it ensured that the accounts of the Fisherton birth published by L'Estrange were devoid of the political rhetoric that had characterized the Kirkham prodigy in 1646, the publication of which was not impeded by the strictures of censorship. ${ }^{\text {xii }}$ It is not surprising that when the Press Act lapsed in 1679, the crisis of truth created by the Popish Plot and Exclusion crisis produced another slew of pamphlets rehearsing the familiar tropes of political monstrosity some of which targeted L'Estrange himself. ${ }^{\text {xiii }}$

The printed accounts of the Fisherton monster are therefore suggestive of how the rejection of partisan politics was not only the conscious endeavour of the Royal Society but also a necessity for others wishing to see their work in print. As we have seen, the Society's approach to monstrosity also influenced the climate in which Natures wonder? and The true picture were produced: both broadsheets bore some of 
the hallmarks of the natural philosophical interpretation of monstrosity in the image of the twins presented in The true picture and in the testimony of Josiah Smith in Natures wonder? Futhermore, Burns has argued that governmental attempts to stigmatize political prodigies as the ravings of fringe factions, exemplified by the Anglican response to the Fairford frogs, were themselves reinforced by the growing authority of natural philosophy. ${ }^{\text {xciv }}$ Since the Society had received the endorsement of Charles II, its corporate activities also owed something to the authority of the state, even as its fellows eschewed political interpretation in their writings and political discussion at their meetings. For Burns this contributes to his thesis of the marginalization of providential monsters from 'reverence to ridicule' across this period and belongs to the same paradigm of 'disenchantment' used by Pender to explore the Fisherton monster. The compatibility of natural philosophical, spiritual, and providential readings of monstrosity evidenced in the case of the Fisherton monster complicates this account of a shift in attitudes towards monstrosity. But Burns's analysis of the conditions in which these varied interpretations of monstrosity were produced is also highly suggestive of the value of a different approach both to this episode and to the historiography of monstrosity in the Restoration period more generally. The Waterman twins were born at a moment when partisan political, as opposed to more broadly providential, monsters were being discouraged. The Fisherton monster is the product of this particular moment and of a culture that both censored potentially subversive material and extolled the virtues of an alternative conception of truth in the form of early Restoration natural philosophy. In other words, the Fisherton monster embodies a series of mutually reinforcing responses to the memory of an earlier period of political instability. 
V.

This article has argued that our understanding of contemporary responses to the Fisherton monster is not complete without an appreciation of how the past was brought to bear on the early Restoration present. It has suggested that accounts of the monster were profoundly shaped by the legacies of the 1640s and the politicized vision of monstrosity engendered and sustained by the conflict. In this respect it has echoed studies of the aftermath of the Civil Wars in other spheres: the window onto the politics of healing provided by Peter Elmer's examination of the Irish healer Valentine Greatrakes - a 'vantage point from which to observe contemporaries struggling to make sense of a world that had been thoroughly turned upside down by decades of civil war and religious and political strife ${ }^{\text {xcv }}$ - and the challenges to authority embedded in the mid-seventeenth-century politics of reproduction and the female body explored by Mary Fissell. ${ }^{\text {xcvi }}$ Indeed monstrosity was one among many categories destabilized by the mid-century conflict, 'a struggle of cosmic proportions' that, as Elmer has argued, also destabilized the concept of witchcraft, which too became the "prey of faction and party, an instrument more likely to encourage continuing division and schism than religious and political harmony'. ${ }^{\text {xcvii }}$ It was in light of this general period of struggle that the Fisherton authors and correspondents developed their accounts of Mary and Martha Waterman.

The compatibility of the natural philosophical, spiritual, and providential accounts of the Fisherton monster is properly understood as a series of overlapping responses to the memory of this period of profound instability. The 'fluid interchange' 
between 'science' and providence that characterizes Pender's account of the episode is partly the product of these attempts to negotiate the problematic past by turning to alternative conceptions of truth. ${ }^{\text {xcviii }}$ The Fisherton monster was not interpreted as a political symbol precisely because it embodied forms of truth developed and deployed to transcend the embattled pluralism of the political sphere. The monster, once an emblem of societal divisions, came in the 1660 s to reflect a new impulse to forget. The rejection of sectarian politics was made particularly explicit in the case of the Royal Society virtuosi and their peers, who, as some of the first witnesses to the birth, provided commentaries on the Fisherton monster that influenced subsequent printed accounts. Their self-proclaimed authority on the matter and ability not only to observe but also experiment on the Waterman twins by way of dissection - which would have been impossible in the case of, for example, the Fairford frogs - may also have made their interpretation particularly influential. Nevertheless, this article has endeavoured to set the Society's rejection of partisan politics in the broader context of the postCivil War instinct to bury the 1640s and 1650s in oblivion, including through the mechanism of licensing, which acted as a disincentive to the production of political monsters and redefined what was politically acceptable in accounts of unusual phenomena.

The 1660 s was a decade in the shadow of civil war. Studies of later Stuart political culture have highlighted the inability of the Restoration Settlement to transcend partisan divisions and the subsequent entrenchment of pluralism in English society, focusing on the myriad ways in which this culture invoked the memory of the 1640s and 1650s. ${ }^{\text {xcix }}$ But by addressing the issue of forgetting the Civil Wars through the lens of monstrosity, this article has suggested that in the 1660s the instinct to forget was both more widespread and more successful than has been implied by this 
emphasis on recollection and commemoration. The absence of political commentary in accounts of the Fisherton monster is one example of the strength, reach, and consequences of an early Restoration culture of amnesia. If contemporary accounts of the Fisherton monster were concerned with the natural, spiritual, and moral truths located within physical deformity, they also offered an alternative to partisan conceptions of truth and, therefore, a means of forgetting the problematic politics of the civil war past.

Christ's College, Cambridge, CB2 3BU hk130@cam.ac.uk

* I am very grateful to Alex Walsham both for supervisory guidance during the preparation of the MPhil dissertation upon which this article is based and for commenting on its various drafts. I also wish to thank Carys Brown, Liesbeth Corens, and David Reynolds for reading and commenting on earlier versions, Sachiko Kusukawa for guidance on the role of images at the Royal Society, and Phil Withington and the anonymous referees for the Journal for their helpful suggestions. I acknowledge the support of the Arts and Humanities Research Council through the award of an MPhil studentship.

${ }^{i}$ Stephen Pender, “"No monsters at the resurrection": inside some conjoined twins', in Jeffrey Jerome Cohen, ed., Monster theory: reading culture (Minneapolis, MN, and London, 1996), pp. 143-67, at pp. 143-5. See also A.W. Bates, Emblematic monsters: unnatural conceptions and deformed births in early modern Europe (Amsterdam and New York, NY, 2005), pp. 99100.

ii Pender, 'No monsters at the resurrection', p. 145.

iii David Cressy, Bonfires and bells: national memory and the Protestant calendar in Elizabethan and Stuart England (Berkeley and Los Angeles, CA, 1989), ch. 11; idem, 'Remembrancers of the Revolution: histories and historiographies of the 1640s', Huntington Library Quarterly, 68 (2005), pp. 257-68; Matthew Neufeld, The Civil Wars after 1660: 
public remembering in late Stuart England (Woodbridge, 2013); Mark Stoyle, 'Remembering the English Civil Wars', in Peter Gray and Kendrick Oliver, eds., The memory of catastrophe (Manchester, 2004), pp. 19-30; Blair Worden, Roundhead reputations: the English Civil War and the passions of posterity (London, 2002).

${ }^{\text {iv }}$ See Neufeld, Civil Wars after 1660, p. 4; Ross Poole, 'Enacting oblivion', International Journal of Politics, Culture, and Society, 22 (2009), pp. 149-57.

${ }^{\mathrm{v}}$ Neufeld, Civil Wars after 1660, p. 5 and passim.

${ }^{\text {vi }}$ Paul Slack, 'Poverty and politics in Salisbury, 1597-1666', in Peter Clark and Paul Slack, eds., Crisis and order in English towns, 1500-1700: essays in urban history (London, 1972), pp. 164-203, at p. 165 .

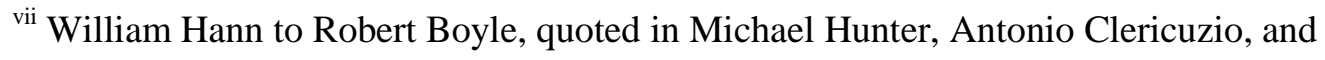
Lawrence M. Principe, eds., The correspondence of Robert Boyle (6 vols., London, 2001), II, pp. $423-4$.

${ }^{\text {viii }}$ Robert Latham and William Matthews, eds., The diary of Samuel Pepys (11 vols., London, 1970-83), V, p. 319.

${ }^{\text {ix }}$ Chippenham, Wiltshire and Swindon Archives, 1902/1.

${ }^{\mathrm{x}}$ Bates, Emblematic monsters, pp. 17-18 and appendix.

${ }^{x i}$ Ibid. See also Dudley Wilson, Signs and portents: monstrous births from the Middle Ages to the Enlightenment (London, 1993), chs. 2-4.

${ }^{x i i}$ The originals do not survive but Boyle copied their content verbatim to Oldenburg. See London, Royal Society (hereafter RS), EL/B1/82.

${ }^{\text {xiii }}$ A. Rupert Hall and Marie Boas Hall, eds., The correspondence of Henry Oldenburg (13 vols., Madison, WI, 1965-86), II, p. 280, n. 4. For the letter see RS, EL/OB/21.

${ }^{\text {xiv }}$ RS, EL/B1/82. On the popularity of monsters at the Society see Palmira Fontes da Costa, 'The medical understanding of monstrous births at the Royal Society of London during the first half of the eighteenth century', History and Philosophy of the Life Sciences, 26 (2004), pp. $157-75$, at pp. $158-9$. 
${ }^{\mathrm{xv}} \mathrm{RS}, \mathrm{EL} / \mathrm{B} 1 / 82$.

${ }^{\mathrm{xvi}}$ Thomas Birch, The history of the Royal Society of London, for improving of natural knowledge (4 vols., London, 1756-7), IV, p. 480.

${ }^{\text {xvii }}$ On the 'new experimental science' see Pamela H. Smith, 'Science on the move: recent trends in the history of early modern science', Renaissance Quarterly, 62 (2009), pp. 345-75, at p. 345 .

${ }^{x v i i i}$ Francis Bacon, The new organon, ed. Lisa Jardine and Michael Silverthorne (Cambridge, 2000), p. 33.

${ }^{\text {xix }}$ Ibid., p. 225.

${ }^{\mathrm{xx}}$ Ibid., p. 149.

${ }^{x x i}$ Lorraine J. Daston, 'Baconian facts, academic civility and the pre-history of objectivity', Annals of Scholarship, 8 (1991), pp. 337-63, at pp. 346-7.

${ }^{\text {xxii } H e n r y ~ O l d e n b u r g, ~ ' T h e ~ i n t r o d u c t i o n ', ~ P h i l o s o p h i c a l ~ T r a n s a c t i o n s ~ o f ~ t h e ~ R o y a l ~ S o c i e t y ~ o f ~}$ London, 1 (1665), pp. 1-2.

xxiii Michael Hunter, 'The Royal Society and the decline of magic', The Royal Society Journal of the History of Science, 65 (2011), pp. 103-19, at p. 104.

${ }^{x x i v}$ Paula Findlen, Possessing nature: museums, collecting, and scientific culture in early modern Italy (Berkeley and Los Angeles, CA, and London, 1996), p. 207.

${ }^{\mathrm{xxv}} \mathrm{RS}, \mathrm{Cl} . \mathrm{P} / 13 / 2$.

${ }^{x x v i}$ Though they are not signed by Hann, the detail of the images and the ink used suggests that they were his work. They are preserved with his letter in RS, Cl.P/13/2.

${ }^{\text {xxvii }}$ Sachiko Kusukawa, 'Picturing knowledge in the early Royal Society: the examples of Richard Waller and Henry Hunt', Notes and Records of the Royal Society, 65 (2011), pp. 27394; eadem, Picturing the book of nature: image, text, and argument in sixteenth-century human anatomy and medical botany (Chicago, IL, 2012); Palmira Fontes da Costa, 'The making of extraordinary facts: authentication of singularities of nature at the Royal Society of 
London in the first half of the eighteenth century, Studies in History and Philosophy of Science, 33 (2002), pp. 265-88, at pp. 270-6.

${ }^{\text {xxviii }}$ Peter Parshall, 'Imago contrafacta: images and facts in the Northern Renaissance', Art History, 16 (1993), pp. 554-79, at p. 555.

${ }^{\text {xxix }}$ Kusukawa, 'Picturing knowledge', p. 289.

${ }^{\mathrm{xxx}}$ Peter Dear, 'Totius in verba: rhetoric and authority in the early Royal Society, Isis, 76 (1985), pp. 144-61, at pp. 152-3.

${ }^{\text {xxxi }}$ Kusukawa, 'Picturing knowledge', p. 288.

${ }^{x x x i i} \mathrm{RS}, \mathrm{EL} / \mathrm{OB} / 23$.

${ }^{\text {xxxiii }} \mathrm{RS}, \mathrm{EL} / \mathrm{B} 1 / 82$.

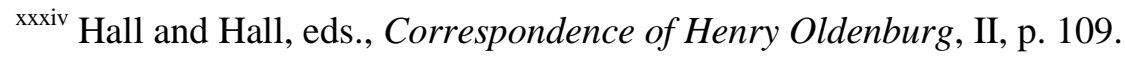

${ }^{\mathrm{xxxv}}$ da Costa, 'Extraordinary facts', p. 276.

${ }^{\mathrm{xxxvi}}$ Steven Shapin, A social history of truth: civility and science in seventeenth-century England (Chicago, IL, and London, 1994), p. xxvi.

${ }^{x x x v i i} \mathrm{RS}, \mathrm{EL} / \mathrm{B} 1 / 82$.

${ }^{\text {xxxviii }}$ Hunter et al, Correspondence of Robert Boyle, II, p. 395.

${ }^{\text {xxxix }} \mathrm{RS}, \mathrm{Cl} . \mathrm{P} / 13 / 2$.

${ }^{\mathrm{xl}}$ da Costa, 'Extraordinary facts', p. 281.

${ }^{x l i}$ Hunter et al., Correspondence of Robert Boyle, II, p. 385.

xlii For the etymology of 'monster' see Bates, Emblematic monsters, p. 12.

xliii Kathryn M. Brammall, 'Monstrous metamorphosis: nature, morality, and the rhetoric of monstrosity in Tudor England', Sixteenth Century Journal, 27 (1996), pp. 3-21, at pp. 15-18. On the providential and political character of monstrosity see William E. Burns, An age of wonders: prodigies, politics, and providence in England, 1657-1727 (Manchester, 2002), pp. 1-5; Alexandra Walsham, Providence in early modern England (Oxford, 1999), ch. 4.

xliv Brammall, 'Monstrous metamorphosis', p. 6. 
${ }^{\mathrm{xlv}}$ The kingdomes monster uncloaked from heaven: the popish conspirators, malignant plotters, cruell Irish, in one body to destroy kingdome, religion and lawes (London, 1643). ${ }^{\mathrm{xlvi}}$ A declaration of a strange and wonderfull monster: born in Kirkham parish in Lancashire (London, 1646), p. 1.

${ }^{\text {xlvii }}$ See for example The soundheads description of the Roundhead or the Roundhead exactly anatomized in his integralls and excrementalls, by the untwisting a three-fold knott (London, 1642) and contrast with the portrayal of the Cavaliers in Englands wolfe with eagles clawes (London, 1647).

${ }^{x l v i i i}$ Michael Hunter, Science and the shape of orthodoxy: intellectual change in late seventeenth-century Britain (Woodbridge, 1995), p. 14.

${ }^{x l i x}$ Marie Boas Hall, Henry Oldenburg: shaping the Royal Society (Oxford, 2002), p. 56.

${ }^{1}$ Marie Boas Hall, 'Oldenburg, Henry (c.1619-1677)', ODNB.

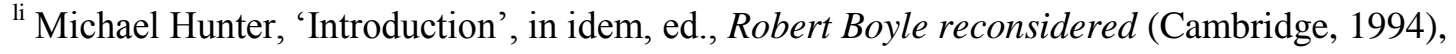
pp. 1-18, at p. 6 .

lii Barbara Beigun Kaplan, ‘Turberville, Daubeney (1612-1696)’, ODNB.

liii Though it should be noted that Sprat's History was written without the close supervision of the Society. See Michael Hunter, 'Latitudinarianism and the "ideology" of the early Royal Society: Thomas Sprat's History of the Royal Society (1667) reconsidered', in idem, Establishing the new science: the experience of the early Royal Society (Woodbridge, 1989), pp. 199-216.

liv Thomas Sprat, The history of the Royal Society of London, for the improving of natural knowledge (London, 1667), sig. G2r.

${ }^{\text {lv }}$ Ibid., sigs. O4r-Pr.

${ }^{\text {lvi }}$ Dear, 'Totius in verba', p. 159.

${ }^{\text {lvii }}$ Max Weber, The Protestant ethic and the spirit of capitalism, trans. Talcott Parsons (London and New York, NY, 1992). For Weber's influence on early modern historiography see for example Keith Thomas, Religion and the decline of magic: studies in popular beliefs 
in sixteenth and seventeenth-century England, ( $4^{\text {th }}$ edn, London, 1997) and on the history of science see Thomas S. Kuhn, The structure of scientific revolutions (Chicago, IL, 1962). For two important qualifications of the 'disenchantment' thesis see R. W. Scribner, 'The Reformation, popular magic, and the "disenchantment of the world", Journal of Interdisciplinary History, 23 (1993), pp. 475-94, and Alexandra Walsham, 'The Reformation and the "disenchantment of the world" reassessed', Historical Journal, 51 (2008), pp. 497528.

lviii Lorraine J. Daston and Katharine Park, 'Unnatural conceptions: the study of monsters in sixteenth- and seventeenth-century France and England', Past and Present, 92 (1981), pp. 2054, at p. 24. See also Daston and Park, Wonders and the order of nature, 1150-1750 (New York, NY, 1998), p. 336.

${ }^{\text {lix }}$ Walsham, Providence, pp. 194-5.

${ }^{\mathrm{lx}}$ Bates, Emblematic monsters, p. 21.

${ }^{1 x i}$ Findlen, Possessing nature, p. 55.

${ }^{\text {Ixii }}$ Katie Whitaker, 'The culture of curiosity', in N. Jardine, J. A. Secord, and E. C. Spary, eds., Cultures of natural history (Cambridge, 1996), p. 81.

lxiii Ibid, p. 82.

${ }^{\text {lxiv }}$ Hunter et al., Correspondence of Robert Boyle, II, p. 423.

${ }^{\text {lxv }}$ Ibid., II, p. 424.

${ }^{\text {lxvi }}$ On the civility of science see Daston, 'Baconian facts', pp. 352-3; Jonathan Sawday, The body emblazoned: dissection and the human body in Renaissance culture (London and New York, NY, 1995), pp. 242-5; Simon Schaffer and Steven Shapin, Leviathan and the air-pump: Hobbes, Boyle, and the experimental life (Princeton, NJ, and Oxford, 1985); Whitaker, 'Culture of curiosity', p. 75.

${ }^{\text {lxvii }}$ Baskett is described as a 'gentleman of Salisbury' in the Oxford Dictionary of National Biography entry for his son, John. See William Gibson, 'Baskett, John (1664/5-1742)', $O D N B$. 


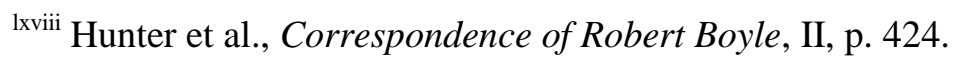

${ }^{\text {lxix }}$ Oxford, Bodleian Library, MS Aubrey 3.

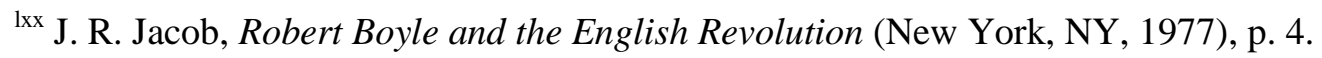

${ }^{1 \times x i}$ The true picture of a female monster born near Salisbury (London, 1664).

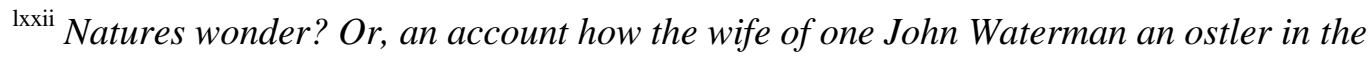
parish of Fisherton-Anger, near Salisbury, was delivered of a strange monster upon the $26^{\text {th }}$ of October 1664 (London, 1664).

lxxiii Hunter et al., Correspondence of Robert Boyle, II, p. 424.

${ }^{\text {lxxiv }} \mathrm{RS}, \mathrm{Cl} . \mathrm{P} / 13 / 2$.

${ }^{\mathrm{lxxv}}$ Natures wonder?

${ }^{\text {lxxvi }}$ Walsham, Providence, pp. 198-203.

Ixxvii I am grateful to Sachiko Kusukawa for the suggestion that the woodcut in Natures wonder? is a copy of the image in The true picture.

lxxviii Oxford, Bodleian Library, MS Aubrey 3.

${ }^{\text {Ixxix }}$ Strange and true news from Gloucester (London, 1660), p. 2, quoted in Jerome Friedman, Miracles and the pulp press during the English Revolution: the battle of the frogs and Fairford's flies (London, 1993), p. 248.

${ }^{1 \times x x}$ Robert Clark, The lying-wonders, or rather, the wonderful-lyes, which was lately published to the world, in a lying-pamphlet (called strange and true news from Gloucester) (London, 1660); Henry Jessey, The Lord's loud call to England (London, 1660), p. 5, quoted in Friedman, Miracles and the pulp press, p. 251.

${ }^{\text {lxxxi }}$ Clark, The lying wonders, p. 5, quoted in Friedman, Miracles and the pulp press, p. 249.

${ }^{\text {lxxxii }}$ For two approaches to the instability of truth in this period see Mark Knights, Representation and misrepresentation in later Stuart Britain: partisanship and political culture (Oxford, 2005) and Frances E. Dolan, True relations: reading, literature, and evidence in seventeenth-century England (Philadelphia, PA, 2013). lxxxiii Friedman, Miracles and the pulp press, pp. 256-7. 
${ }^{\text {lxxxiv }}$ Burns, Age of wonders, p. 20.

${ }^{\text {lxxxv }}$ Ibid., p. 27.

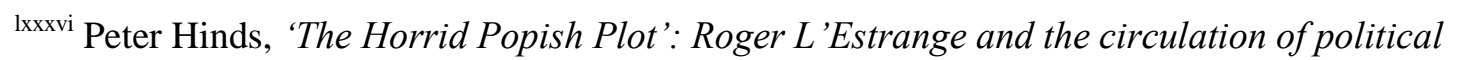
discourse in late seventeenth-century London (Oxford, 2010), pp. 36-7.

Ixxxvii Calendar of State Papers Domestic, 1661-2, p. 282, quoted in Beth Lynch, 'Rhetoricating and identity in L'Estrange's early career, 1659-1662', in Anne Dunan-Page and Beth Lynch, eds., Roger L'Estrange and the making of Restoration culture (Aldershot, 2008), pp. 7-26, at p. 18; Peter Hinds, “Tales and romantick stories": "impostures”, trustworthiness and the credibility of information in the late seventeenth century', in DunanPage and Lynch, eds., Roger L'Estrange, pp. 89-107, at p. 106.

Ixxxviii Annabel Patterson, Censorship and interpretation: the conditions of writing and reading in early modern England (Madison, WI, 1984), pp. 10-11 and passim.

Ixxix Burns, Age of wonders, p. 38.

${ }^{x c}$ Lynch, 'L’Estrange's early career', p. 26.

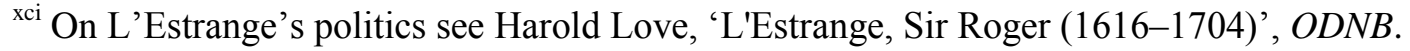

${ }^{x c i i}$ On the limits of censorship see Tim Harris, London crowds in the reign of Charles II: propaganda and politics from the Restoration until the Exclusion Crisis (Cambridge, 1990), p. 28; Knights, Representation and misrepresentation, p. 7.

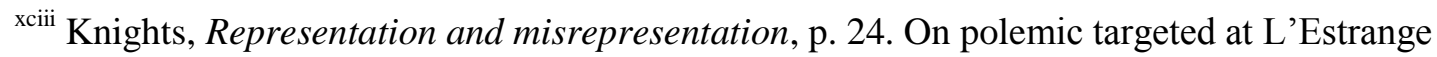
see Helen Pierce, 'The Devil's bloodhound: Roger L'Estrange caricatured', in Michael Hunter, ed., Printed images in early modern Britain: essays in interpretation (Aldershot, 2010), pp. 237-54.

${ }^{\text {xciv }}$ Burns, Age of wonders.

${ }^{\mathrm{xcv}}$ Peter Elmer, The miraculous conformist: Valentine Greatrakes, the body politic, and the politics of healing in Restoration Britain (Oxford, 2012), p. v.

${ }^{\text {xcvi }}$ Mary E. Fissell, Vernacular bodies: the politics of reproduction in early modern England (Cambridge, 1991), ch. 6. 
${ }^{\text {xcvii }}$ Peter Elmer, "'Saints or Sorcerers”: Quakerism, Demonology, and the Decline of

Witchcraft in Seventeenth-century England', in Jonathan Barry, Marianne Hester, and Gareth Roberts, eds., Witchcraft in early modern Europe: studies in culture and belief (Cambridge, 1998), pp. 145-180, at p. 174.

xcviii Pender, 'No monsters at the resurrection'.

${ }^{x c i x}$ Cressy, Bonfires and bells, ch. 11; Knights, Representation and misrepresentation, p. 84 and passim; N. H. Keeble, The Restoration: England in the 1660s (Oxford, 2002), ch. 6; Neufeld, Civil Wars after 1660; Stoyle, 'Remembering the English Civil Wars'. 